\title{
"Co Regency" Throne share in Modern Egypt 1805-1952
}

\author{
Enas Fares Yehia \\ Lecturer - Tourism Guidance Department \\ Faculty of Tourism and Hotels Minia University
}

\begin{abstract}
Co-regency was common in ancient Egypt, and was always between the king and his son. In modern Egypt regency was also used, although not as widely as in ancient Egypt. Regency has not always been from father to son, there were many cases in which the regent was not a son, sometimes councils were formed to serve as a regent for the ruler. The most famous regency case in Modern Egypt was that of King Farouk after the death of his father King Fouad. The aim of this article is to examine the regency system in Modern Egypt. Actually, there were many advantages to the regency system, as it would prepare the future ruler to rule, and submit to the control of the government. Also, there were disadvantages of regency, as it might give the opportunity for the seizure of the throne by the regent.
\end{abstract}

Keywords: Modern Egypt, Regency, Succession

\section{Definition}

Co regency or co-principality is the situation where a monarchical position (such as king, queen, emperor or empress) normally held by only a single person, is held by two or more. ${ }^{1}$

\section{A regent is:}

1. One who rules during the minority, absence, or disability of a monarch.

2. One acting as a ruler or governor.

In political systems where power is concentrated in the hands of one person as in Egypt, transferring rule is always a difficult matter. The new ruler needs to establish authority immediately and convince others to obey him, and at the same time he needs to learn the rules of the job. In order to smooth the transition, the Egyptians, at some point in their history, initiated the idea of co-regency.

\footnotetext{
${ }^{1}$ https://en.oxforddictionaries.com/definition/regent; http://www.encyclo.co.uk/meaning-of-Coregency
} 


\section{Succession Strategy in Modern Egypt}

After the departure of the French Expedition from Egypt in 1801, the Ottoman Sultan found it an opportunity to re-establish his control over Egypt. He decided to get rid of the remaining Mamluks, but in fact the Mamluks during that time were weaker than what he thought. The British also were not excluded from the scene, they wanted to appoint Allalphi Bek, one of the Mamluks, as a ruler of Egypt to be their tool there, but they failed in the matter. The period that followed the French evacuation also witnessed breakdown of law and order. It enhanced the Ulma who had tremendous power, they advised the ruler in political matters, interpreted the laws and set the rules for society as a whole. They were not only religious leaders, but the nation's political leaders as well. ${ }^{2}$ Egypt was ruled by the Ottoman Caliphate through its representative(Wali), as a province of the Ottoman Empire from the Ottoman conquest in 1517. The bad circumstances in Egypt during this era led the Sultan to isolate many Walis from their position, till he appointed Khurshid Pasha who was a hateful ruler for the Egyptians, the Mamluks, and even the Albanian soldiers. The Ulma then brought Mohamed Ali to power proclaiming him as the new Wali who ruled Egypt from 1805 till 1848, the royal family was started by Mohammed Ali Pasha.

The ruling families are the descendents in the male line of a common male ancestor, whose name the family takes ${ }^{3}$. In 1840 Mohammed Ali was permitted a Edict after the terms of the London Treaty ${ }^{4}$ to pass control of Egypt down to his heirs ${ }^{5}$, following Ottoman succession practice, to the eldest male of the royal family, with the following conditions ${ }^{6}$ :

- $\quad$ The rule should be in a direct line from the elder male, among the sons and grandsons. The nomination should be made by the Sublime Porte.

- $\quad$ The daughters of the dynasty have no right to rule.

Actually, this Edict granted the dynasty succession, and placed Egypt under the Ottoman practice. It prepared the way for struggles between the sons of the royal family. Mohammed Ali had tried to wrest more rights for his successors, as he knew that those successors would have a difficult time ${ }^{7}$. Problems appeared clearly when Ismail became the heir. His elder brother Ahmed Rifcat was killed in a railway accident, and there was rumours that Ismail was behind the matter ${ }^{8}$.

In 1866 Khedive Ismail, in return for large sums of money for the Sultan, had obtained a new law of succession, in which the rule of Egypt transferred from the father to the eldest son, or, if there

\footnotetext{
${ }^{2}$ Nadia Ramses Farah, Egypt's Political Economy. Power Relations in Development, ( American University in Cairo press, 2009), p.98.

${ }^{3}$ Michael Herb, All in the Family, Absolutism, Revolution, and Democracy in the Middle Eastern Monarchies, (State University Press, New York, 1999), p.27.

${ }^{4}$ London treaty was a four-power European agreement imposing settlement on Mohamed Ali. By it he had lost his possession of Syria, Crete, and the Hijaz.

5 Actes Diplomatiques et Firmans Imperiaux Relatifs a L'Egypt, (Cairo, 1880), p. 9.

${ }^{6}$ Melvin E. Page and Penny M. Sonnenburg (ed.), Colonialism. An International Social, Cultural, and Political Encyclopedia,(ABC. CLIo, Inc. California, 2003), p. 1071.

${ }^{7}$ Afaf Lutfi Alsayed Marsot, A Short History of Modern Egypt, (Cambridge University Press, 1985), p. 65.

8 Beshara Boumani (ed.), Family History in the Middle East, Household, Property, and Gender, (State University, New York, 2003), p. 259.
} 
were no sons, to the eldest nephew, with the regency rule if the heir was a minor ${ }^{9}$. On $8^{\text {th }}$ June 1873, this Edict ${ }^{10}$ with the order of succession was confirmed ${ }^{11}$. According to the system of hierarchy, Mustafa Fazil the brother of Khedive Ismail was next in line after Khedive, so Khedive Ismail obtained a firman from the Sublime Porte to change the law of succession in favour of his son Tewfik.

The succession rules were changed with Egypt's changing status. After the declaration of the British protectorate over Egypt in 1914 during World War I and the consequent secession of Egypt from the Ottoman Empire, succession had no longer confirmed by an Edict of the Sultan. Consequently, Egypt was under the British protectorate, and Khedive became Sultan. The new status required new laws to regulate the monarchy after the 1919 Revolution and the Declaration of 28 February 1922, so the law of succession for Mohamed Ali's family was promulgated on 12 April 1922, with these terms ${ }^{12}$ :

- $\quad$ "A minor king should have a guardianship council, which will take the powers of the king till reaching the majority age."

- $\quad$ "This guardianship council must consist of three members who are chosen by the king. The selections should be registered in a document issued with two original copies, one is deposited with the Cabinet, and the other is deposited with the Prime Minister."

- $\quad$ "These documents will remain inside sealed envelopes till the death of the king, after that they will be opened in front of the parliament. The members of the chosen council must be Egyptian and chosen from the following: princes, and other members of the Royal family, Prime Ministers, Parliament Speakers, ministers, and finally Senate members. Furthermore, the selection must be approved by parliament."

With regard to the regency, the deprivation of rights and so on which have hitherto been invested solely in the ruler had now been made subject to the approval of the Egyptian parliament. This is considered a highly important departure constituting a visible sign of the changing order of things in Egypt.

\section{The Regency Cases in Modern Egypt}

\section{Regency during the Incapacity of the Ruler}

The only case here was that of Ibrahim Pasha (Fig. I), Son of Mohammed Ali.

Mohammed Ali Pasha had three sons Ibrahim, Touson and Ismail. Ibrahim was the eldest. Both Touson and Ismail died during the life of their father ${ }^{13}$. So Ibrahim Pasha inherited the Viceroy

\footnotetext{
${ }^{9}$ Evelyn Baring, Modern Egypt, (Cambridge University Press, 2010), p. 122. Firman addressed by the Sultan to the Viceroy of Egypt, modifying the order of succession, and granting certain privileges, 27th May, 1866.

${ }^{10}$ Alwaqaec Almasrya, issue 517, 17 July 1873.

11 Stanford J. Shaw and Ezel Kural Shaw, History of the Ottoman Empire and Modern Turkey. Reform, Revolution, and Republic, Vol. II, (Cambridge University Press, 1977), p. 145.

${ }_{12}^{12}$ Percy F. Martin, Egypt- Old and New, (Rutledge Press, New York, 1923), p. 136.

13 J. S. Buckingham, Esq., M. P. (ed.), The Parliamentary Review, Vol II, Session of 1834, (London, MDCCCXXXIV), p. 890.
} 
title in April 1848. Ibrahim pasha was born in 1789 at Cavalla. During the early days of his father's rule he stayed with his mother in Cavalla. After his arrival in Egypt he was appointed Governor of the Stronghold in the Citadel $^{14}$.

Ibrahim Pasha was well prepared for ruling the country. He was assigned to command an army to march against the Mamlukes in Upper Egypt. He attacked them and expelled them into Nubia, and in 1809 he was appointed governor of Upper Egypt. At the age of seventeen he joined the Egyptian army in which he attained a prominent position. His military activities earned him

the title of the Governor of Levant, and he followed his father's vision, introducing economic reforms ${ }^{15}$.

He was a talented military leader. In 1816, after the death of his brother Touson, he was sent to Arabia in a war against the Wahabs. He captured the holy towns of Mecca and Madina, and he was received in triumph after his return to Cairo ${ }^{16}$. He was given the title Pasha after his return. In 1824, he led an expedition to Greece, but the Egyptian fleet was destroyed in the Navarino Battle and Ibrahim committed great excesses and cruelties. In 1831, he was sent to Syria where he displayed military talent, such that Gaza, Hiffa and Jaffa fell into his hands and Acre opened its gates to him after a siege of six months ${ }^{17}$.

Ibrahim Pasha was regarded as the hero of modern Egypt. His conquests were confined to Syria, of which he kept possession till 1839, and where he established his father's rule with success and organised the country in an admirable manner. His rule in Syria and Palestine continued until 1841, and during these ten years Ibrahim Pasha was, in fact, the ruler of the country and he tried to introduce new systems, like his father ${ }^{18}$. During this time, he had an opportunity to reach Constantinople, but the European powers interfered and stopped his progress ${ }^{19}$. After his evacuation from Syria he devoted his attention to agriculture and introduced many improvements in the cultivation of the land. He always showed the greatest respect for his father though enjoying the high titles of Vizier and Governor of $\mathrm{Mecca}^{20}$.

From April 1847, the administration of Egypt was left to Ibrahim, due to Muhammad Ali Pasha's declining physical and mental health. Ibrahim Pasha acted as the real ruler of the country, but formally Mohammed Ali was the ruler and Ibrahim was just his regent. He determined to go to Istanbul and ask for investiture as a ruler of Egypt, during his father's lifetime ${ }^{21}$. Ibrahim Pasha

\footnotetext{
${ }^{14}$ Pierre Crabites, Ibrahim of Egypt, (Rutledge, New York, 2013), p. 5.

${ }^{15}$ Lesley Lababidi, Cairo's Street Stories, (AUC press, Cairo, 2008), p. 62.

${ }_{17}$ N.C. Chattervi, Muddle of the Middle East, (Abhinav Publications, New Delhi, 1973), p. 171.

${ }^{17}$ Latitia W. Ufford, The Pasha, How Mehmet Ali Defied the West 1839-1841, (McFarland Company Inc.
} Publishers, Carolina, 2007), p. 104.

${ }^{18}$ Michael Avi. Yonah (ed.), A History of Israel and the Holy Land, (The Continuum International Publishing Group Inc, New York, 2001), p. 315.

${ }^{19}$ Khaled Fahmy, All the Pasha's Men, Mohamed Ali. His Army and the Making of Modern Egypt, (AUC Press, Cairo, 1997), p. 183.

\footnotetext{
${ }^{21}$ Afaf Lutfi Alsayed Marsot, Egypt in the Reign of Mohammed Ali, (Cambridge University Press, 1984), p.
} p. 82 .

${ }^{20}$ Sylvanus Urban, Gent, The Gentleman's Magazine, Vol. 31, (John Bower Nichols and Son, London, 1849), 256. 
became the ruler of the country on 20 July1847. An envoy of Sublime Porte arrived in Alexandria with the firman by which the Porte recognised Ibrahim Pasha as Egypt's new ruler. However, his reign was very brief, as his death occurred shortly after his return to Cairo. He died on 10 November 1848, due to ill health, thus predeceasing his father ${ }^{22}$.

He was the shortest-reigning ruler of the dynasty. The duration of his rule depends on whether or not his reign as regent is taken into account. Despite the short length of his reign, Ibrahim Pasha is far from being an historically unimportant figure, as most of his significant achievements were made before his accession to the throne.

In this case the regent was a son, and he was well prepared to take on leadership at a young age. Although his regency was during the lifetime of his father, he obtained a firman to be the official ruler of the country. He had the full authority to lead the country as he wanted without any intervention from the ruler who was in a very bad health. During his rule as a regent he cared about strengthening the country borders', and the renewal of its military strength. The firman which he obtained to be the ruler cancelled his role as a regent as by this firman he turned from a regent to a ruler. And if the regency was enough as a tool for rule, so what led the Sublime Porte to have an Edict for Ibrahim to be the ruler.

\section{Regency during the Absence of the Ruler}

Three examples of this regency in modern Egypt:

- $\quad$ The first during the reign of Said Pasha

- $\quad$ Both the second and the third during the era of Khedive Ismail.

\section{The Regency of Ismail during the Reign of Said Pasha}

Said Pasha ascended the throne of Egypt after Abbas Pasha ${ }^{23}$, he was a liberal and tolerant ruler who opened a new program to enlist peasants into the officer corps. He ruled the country for nine years from 1854 to 1863 , he was the one who had awarded the concession to build the Suez Canal in 1854 with a ninety-nine-operating lease to Ferdinand de Lesseps. When the country ran into financial trouble, he bought forty four percent of its stock, in his attempts to modernize the country from stringing telegraph lines up the Nile to expanding the railroad and digging the Suez Canal, he run the government into dept. ${ }^{24}$ Abbas pasha the predecessor of Said Pasha was so cruel in treating all the members of the royal family especially his uncle Said, obliged him to stay in Alexandria, and he returned after the murder of Abbas I. So, when Said Pasha took the throne of Egypt, he treated the members of the royal family in a different way.

Said Pasha trusted Ismail a lot, in 1855 he sent him to Paris on a confidential mission to the Emperor Napoleon, and on his way home he paid a visit to the Pope, he afterwards held important

\footnotetext{
${ }^{22}$ Abd El Rahman El Rafcy, Asr Mohammed Ali, $5^{\text {th }}$ edition, (Dar El Marf, Cairo, 1989), p. 569.

23 Abbas Pasha I was the son of Touson and the grandson of Mohammed Ali, he ruled after the death of Ibrahim Paha.

${ }^{24}$ Robert Fitzgerald, The Rise of the Global Company. Multinationals and the making of the Modern World, (Cambridge University Press, 2015), p.117.
} 
offices under the government of Said Pasha. ${ }^{25}$ Said pasha let him rule the country during his absence. He was not afraid of there being any plot against him from Ismail to take the rule. He trained Ismail and prepared him to be the ruler. He made him his regent twice during his rule, first when he was visiting Syria in $1861^{26}$, and second when he was in Europe in 1862.

Ismail (Fig.II) did not decide important decisions during the absence of his uncle, but he gave great care to preserve the affairs as it was till his Uncles' return. It is worth mentioning here that Said Pasha was satisfied with the regency of Ismail. As soon as he returned from his journey he entrusted Ismail with the command of 14,000 men to put down the rebellion which had broken out on the frontier of Sudan, which he did in an incredibly short space of time. ${ }^{27}$

This in fact reflection of the success of Ismail's rule as a regent during the absence of his uncle, worth mentioning that despite the foreign interface in Egypt's affairs during the reign of Said pasha, both the British and the French were away from this matter they did not refuse or present any comments regarding the system of regency during the absence of said pasha, maybe they regarded it as a short time that in turn would not affect the country.

This was the first case of regency in modern Egypt during the absence of the ruler, but Ismail found it a useful step for preparing to become the ruler, so he made the same arrangement with his son Tewfik.

\section{Regency during the Era of Khedive Ismail}

In 17 January 1863 Said Pasha died at the age of forty-one, Ismail then took the rule of Egypt, he ruled from 1863 to 1879 . He built palaces, parks, railways, roads, and statues. He did all he could to make Egypt like Europe in everything. Khedive Ismail used regency as a tool of rule twice. The

first was via a chosen council formed in June 1867 of Ismail Seddiq, Ismail Ragheb and Mohammed Sherief ${ }^{28}$, during the minority of his son Tewfik, and the second was by his son, after reaching legal age.

The first member of the regency council was Ismail Seddiq (El Mufatish) (Fig.III), he was born in 1830, his mother was the closest maid for the Khedive's mother Khoshiar Hanem. Ismail Seddiq was the brother of infancy for the Khedive, he was appointed as inspector for lower Egypt territories and after his success in the matter he was awarded by the Khedive and was given much authority Permissions, he had the right for appointing and isolating mayors, Chieftains, and the Sheriff. He supervised constructing railway between Banha and Qaluib, also he built a factory for papers. In 1868, he was appointed as the financial minister. ${ }^{29}$

Ismail Seddiq was regarded as the second man in Egypt after the Khedive even the Princes of the royal family were jealous from his influence. Despite all what mentioned about the man and his works in the country, and how he was close for the khedive, the khedive did not let him act as a

\footnotetext{
${ }^{25}$ The Illustrated London Almanac, (Office,198, Strand, 1868), p.23.

${ }^{26}$ Abd El Rahman Al Rafcy, Asr Ismail, Vol.I, 4th edition, (Dar El Macrf, Cairo, 1987), p. 71.

${ }^{27}$ Albert De Burton, Ten Months' Tour in the East, (F. Bowyer Kitto Bishops Gate, London, 1870), p. 110.

${ }^{28}$ F. Robert Hunter, Egypt under the Khedives 1805-1879. From Household Government to Modern Bureaucracy, (AUC Press, Cairo, 1999), p. 146.

${ }^{29}$ El Ethad Newspaper, 20 January 2006, by Helmi El Namnm.
} 
sole regent during his absence. Here we have an important point to discuss that the regency was a very sensitive case for Khedive Ismail, he rejected to appoint a sole regent during his absence as he was afraid of being any plots against him even though the regent was a close and trusted friend for the Khedive. That Ismail Seddiq was the closest friend for Khedive Ismail, but he rejected to appoint him as a sole regent. Ismail differed from his Uncle Said in this matter, it seems that there were no regulations for the regency process during this phase of Egypt's history, the two rulers treated the regency process in a different way although there were few years between the two dates.

The second member of the chosen council was Ismail Ragheb (fig.IV), who was born in Mora in Greece. He held the title of the financial minister from 1858 to 1869, then he was appointed as the jihadist' leader in 1860-1861, in 1863 he held the title of "Supporter of the Khedive". The title did not give him the right to be the sole regent of the country although he was the Parliament Speaker during the regency period, this in turn give him the right to held the rule during the absence of the Khedive. $^{30}$

The third member was Mohamed Sherif Pasha (fig.v), who was called the leader of the Constitutional life in Egypt, he was appointed as the Foreign minister in 1863, interior Minister in 1865, and he was the deputy of the Khedive in Astana in 1865, so he was a high qualified politician to rule the country. After the end of the regency period the Khedive rewarded him by appointing him as president of the tutoring council.

By examining the history of the three members, it appeared clearly that each one of them was qualified enough to act during the absence of the Khedive, his choice for the members of the regency council was well planned, the Khedive was so intelligent in the matter, he brought to rule the suitable ones, despite of his excellent choice he limited their role during his absence nothing mentioned about their regency, they did not take any vital dictions during his absence. This means that although they were well qualified, professional, and close for him he did not trust them a great deal.

\section{Regency of Tawfik}

Tawfik held the rule after the deposit of his father Khedive Ismail (fig.VI), he ruled the country from 1879 to 1892 , he felt compelled to make just such a choice in 1882 when he collaborated with the British expeditionary force against a nationalist movement that had taken control of the Egyptian state. Khedive Ismail was preparing his son Tewfik to be the ruler of the country. This can be seen clearly from the modification of the succession law. Khedive Ismail issued an order in 1870 for Tewfik to be his regent during his absence in Europe. In this case he gave the regent permission to take all his decisions and to act in all important matters. The regency period lasted for three months and sixteen days ${ }^{31}$.

Here the regent was the son of the ruler, so he gave him all the rights to act like him during his absence, he did not prevent him from taking any important dictions for the country. On the other

${ }^{30}$ F. Robert Hunter, Egypt under the Khedives 1805-1879. From Household Government to Modern Bureaucracy, p.146.

${ }^{31}$ Prince Mohammed Ali Tewfik, Bacd Wathaq Tarekhya mn Ahdy Sakeny Aljenan Ismail Pasha wa Tewfik Pasha, (Cairo, 1948), p. 6. 
hand, he determined the regency for specific period, just the absence period, he did not leave it undetermined, this means also that it seems as if he said for his son" you should consider it just a training period and I will never let the throne for you now." The British and the French were away from the scene, they considered the regency period a very short period to affect their goals in the area. So, they did not prevent the Khedive's choice for his son to be the regent. All what Tewfik did as a regent were just orders for promotions in the army and rewards for some officers, he did not issue a decree related to the political, economic, and social life although he had the right to do so, maybe he avoided getting into any troubles till the return of his father.

By analysing the two cases, we can see that when his son was a minor, he formed a council to act in his place during his absence, rather than leave the rule to one person, but when his son was of legal age, he left the entire leadership to him, by way of preparing him to be the ruler. He was afraid of plots against him, if he gave the rule to one person only, other than his son.

There was one case of the regency being rejected in modern Egypt, during the reign of Abbas Helmi II.

\section{Rejecting the Regency during the Reign of Abbas Helmi II}

When Khedive Tewfik died in 1892, his son Abbas Helmi II was seventeen years' old, which complicated the question of the crown prince's succession. Although Tewfik's father, Khedive Ismail, had obtained a decree from the Ottoman Sultan guaranteeing the Mohamed Ali dynasty the hereditary right of succession to the throne of Egypt, succession still had to be confirmed by Edict issued by the Sublime Porte. It was thought this that the Ottomans would take advantage of the crown prince's status by appointing an acting governor. At that time, the Ottomans were strengthening control over their peripheral provinces and threatened to reassert their claim to Sinai. Because of this, both the Egyptian government and the British avoided setting up a regency, which might invite Ottoman intervention ${ }^{32}$.

As a result, they presented the suggestion that, as Egypt was a Muslim country, it was only natural that the age of its ruler should be calculated in accordance with the Islamic calendar. It was the perfect solution. Not only would Egyptian officials embrace it, but Istanbul, the seat of the Islamic Caliphate, could not utter a word against it. It was thus that from the time of Abbas Helmi onward, the age of Egyptian monarchs was reckoned on the basis of the hijra year ${ }^{33}$.

In this case, the importance of regency as a ruling tool appeared clearly. Because of its importance the British government rejected it on the grounds that the Ottoman regent would affect the country.

\section{Regency for Minors}

There were two examples for this type of regency:

\footnotetext{
- $\quad$ The first for King Farouk

- $\quad$ The second for King Ahmed Fouad II
}

\footnotetext{
${ }^{32}$ Arthur Goldschmidt JR, A Brief History of Egypt, (InfoBase Publishing, New York, 2008), p. 93.

${ }^{33}$ Arthur Goldschmidt JR, A Brief History of Egypt, p.93.
} 


\section{Regency Council of King Farouk}

After the death of King Fouad, Farouk I was sixteen years old, and according to the succession law, he had to wait fifteen months and fourteen days before reaching eighteen when he could rule. During this period, the constitutional powers were assumed by a Regency Council. King Fouad had selected the regents after the promulgating of the succession law, at which time Farouk was only two years old. In accordance with the law, two documents listing the regents were issued, placed in sealed envelopes and deposited with the office of the Prime Minister and the Royal Cabinet $^{34}$. The Prime Minister Ali Maher asked the Governmental Issues Department chairman Abd Elhameed Elbadway, to examine the regency matter with all its legality facets. The committee assembled on 29 April, and examined the succession law for Mohammed Ali's family. The Royal Order of 1922 approved the legal age for the rule of the king to be eighteen years old. This meant that King Farouk would be put under regency for one year, three months and two weeks ${ }^{35}$. Concerning the regency, the law ordered the regents to take a constitutional oath in front of the parliament, and this was the first time this was done in modern Egypt.

Here we have an important point to discuss; Egyptian officials were aware of the fact that the succession law required regents to take the constitutional oath in front of the parliament, but there was no parliament. Parliamentary elections were scheduled for 2 May 1936. So, Ali Maher's government felt it necessary to review a national judicial body ${ }^{36}$.

The Governmental Issues Department's opinion of the stipulated period for the parliamentary sessions of ten days, which was issued on 5 May, was impossible. It would be difficult to hold parliamentary elections within the constitutionally fixed ten days ${ }^{37}$. So here was a constitutional problem. The constitution to which the ruling referred was the restored 1923 Constitution, the Judiciary ruled by the possibility of reconvening the parliament, which was created under the 1930 Constitution. As a result, there were only two courses of action; either prolong the ten days in which the regents were to be sworn in until parliamentary elections could be held, or transfer the parliamentary power to approve the Regency Council, to the Cabinet ${ }^{38}$.

The latter course would actually affect the most important rights of parliament. So, they suggested that the parliament brought in by the forthcoming elections would keep the power to approve the regents. Then the cabinet would retain the legislative powers to which it is entitled since the restoration of the 1923 Constitution.

One suggestion was to wait until the new Deputies Chamber was elected. This would then meet the old senate in order to approve the regents, after which the senate would be dissolved and new senate elections would be held two weeks later. Another suggestion was to wait until both the

${ }^{34}$ Al Ahram Newspaper, issue 18452, 27 April 1936.

35 Latifa Mohammed Salim, Farouk wa Seqwat El Malakya fi Masr 1936-1952, (Maktabt Madbouly press, Cairo,1989),p. 27.

${ }^{36}$ Al Ahram Newspaper, issue 18455, 30 April 1936.

37 Al Ahram Newspaper, issue 18455, 30 April 1936.

${ }^{38}$ Al Ahram Newspaper, issue 18455, 30 April 1936. 
houses of parliament were elected so that they could meet in joint session. The objection to that was that it is impossible to hold elections within ten days, during which time parliament must meet to approve the regents, following the death of the king, unless the condition of ten days could be overridden due to the circumstances ${ }^{39}$.

There was also debate concerning which body would open the letters deposited with the Prime Minister's office. The British feared that El-Nahass' exclusion could give rise to problems, and that the Wafd would not accept guidance from the regents, especially on such fundamental issues as negotiations with the British ${ }^{40}$. Lampson's intervention is a reflection of the Britain's informal imperialism in Egypt, in 2 May the three leaders Mohammed Mahmud of the liberal constitutional party, Mostafa Nahass from the Wafd party, and Ismail Sidqi from the people's party held a meeting with Lampson and they discussed the formation of regency council ${ }^{41}$.

In fact, The British ambassador was afraid of the political situation in Europe and wanting to negotiate a treaty with Egypt, they needed a more stable Egyptian government to deal with. They feared of the growing power of Germany and Italy, and they were anxious to secure their position in the Eastern Mediterranean and control of the Suez Canal in the case of war. The treaty was so important for Great Britain; it would supply and train Egypt's army, and assist in its defence in case of war. So, they tried by all means to appoint a trusted and cooperative person in the regency council to help them during their negotiations with the Egyptian government. Actually, the treaty negotiations started before the death of King Fouad, both Lampson and Nahass were the architects of it, and it was a way from the regency council. Prince Mohamed Ali Tewfik together with other members of the regency council appointed the delegation members of signing the treaty in London. On November 1936 Lampson held a meeting with the prince explaining to him the importance of the British support for his rule ${ }^{42}$.

This was the first time in which the role of the British appeared clearly in the regency process, they concentrated widely in the matter because of the length of the regency period, and the war foot situation in which they were. In fact, the formation of the regency council was settled to Britain's satisfaction, although it was appeared for the Egyptians that the newly elected parliament had decided and approved them. The government held urgent consultations, firstly with the leaders of the Wafd Party and then with the National Front, which was made up of the leaders of all Egypt's major political parties. On 3 May 1936, the leaders of the National Front met with the Prime Minister to discuss the regency question and which body would open the letters deposited

${ }^{39}$ Hassan Yousif, AlQasr wa Doroh fi Alsyasah Almasryia 1922-1952, (A Ahram Center for Political and Strategic Studies, Cairo,1982), p. 84.

${ }^{40}$ Sydney Morning Herald Newspaper, 28 April 1936, p. 4.

${ }^{4141}$ Michael T. Thornhill, "In Search of King Farouk the Mohammed Ali Dynasty and the Decline of British Imperialism in Egypt", Challenging Retrenchment, the United States, Great Britain, and the Middle East 1950-1980, Tore T.Petersen(ed.), ( Tapir Academic Press, Trondheim, 2010), p. 51.

${ }^{42}$ Enas Fares Yehia, "Prince Mohamed Ali after the July Revolution 1952 and the Journey of Searching for the Lost”, Journal of the American Research Center In Egypt(JARCE), Vol.51, 2015, p.197. 
with the Prime Minister's office and the office of the Royal Cabinet. The meeting was held the day following the parliamentary elections ${ }^{43}$.

The participants were eager to reach a solution that would satisfy all parties. They resolved to hold senate elections and the final round of Chamber of Deputies elections on 7 May. On the evening of the following day, a joint meeting of both houses of parliament would be held. Although some objected that this day fell one day after the stipulated ten-day period for swearing in the regency council, Ali Maher quickly countered that the ten-day interval actually started not on the day of the king's death but on the morning of the day after ${ }^{44}$.

Fouad I had named in a document the three members who were to serve on the Regency Council ${ }^{45}$ as: Adli Yakan Pasha ${ }^{46}$, Tewfik Nasim Pasha ${ }^{47}$ and Mahmud Fakhri Pasha ${ }^{48}$. However, parliament together with all political parties in an unusual unity rejected King Fouad's choices ${ }^{49}$. The question here is why the parliament rejected Fouad's choice. The argument was that, firstly Adli Yakan had died, and the Wafd Party rejected the appointment of persons who were loyal for the king, but explained that their refusal was because of the death of one of the members of the chosen council ${ }^{50}$.

Apparently, the political parties had already made up their decisions to ignore the recommendations. The Wafd Party leader Mustafa El Nahass had met with Ali Maher and settled upon Prince Mohamed Ali and two other persons who would not be actively involved in politics, or at least not have political party affiliations, Aziz Ezzat and Sherif Sabri. They also resolved to allocate LE50,000 to the Regency Council, LE20,000 to Prince Ali and LE15,000 to each of the other two regents ${ }^{51}$.

Finally, El-Nahass, in his capacity as the leader of Wafd's the majority party, was given the honor to announce the names of the regents agreed upon by the National Front parties. The announcement was greeted with loud applause. The last order was for the regents to be sworn in before the joint houses of parliament. In turn, Prince Mohamed Ali, Abdel-Aziz and Sherif Sabri (fig.VII) recited the oath ${ }^{52}$ : "I swear by Almighty God to uphold the constitution and the laws of Egypt, to safeguard the independence of the nation and to protect its territories, and to remain loyal to the king." Thus the 15-month and three-day countdown to the end of the regency period began.

${ }^{43}$ Al Ahram Newspaper, issue 18459, 4 May 1936.

44 Al Ahram Newspaper, issue 18459, 4 May 1936.

45 Al Ahram Newspaper, issue 18453, 28 April 1936.

46 Adli Yakan (1846-1933), was the Prime Minister of Egypt in 1920, leader of the liberal party, and the political rival of Saad Zaghloul.

${ }^{47}$ Tawfik Nasim pasha was an Egyptian politician who served as the Prime Minister of Egypt between 1920 and 1921, 1922 and 1923, and finally between 1934 and 1936.

${ }^{48}$ Mahmud Fakheri Pasha was the Financial Minister during the first ministry of Tawfik Nasim Pasha, and the Minister of Foreign Aaffairs in the second ministry of Tawfik Nasim. He was the husband of King's Fouad daughter Princess Fawqia.

${ }^{49}$ Michael T. Thornhill, "In Search of King Farouk”, p. 50.

${ }^{50}$ F.O. 371-20107, 20105, J 3560-2-16, Lampson, F.O., Cairo, 27 April, 1936.

${ }^{51}$ Latifa Mohammed Salim, Farouk wa Seqwoot ElMalkaya fi Masr, p. 28.

${ }^{52}$ F.O. 371-20107, 20106, J4105, Lampson-F.O., Cairo, 11 May 1936. 
The first of the regents, Prince Mohammed Ali, was one of the members of the royal family, son of Khedive Abbas Helmi II, and had been heir to the throne until the birth of King Farouk. Aziz Ezzat $^{53}$ began his career in the court of Khedive Isma'il Pasha and was then promoted to Deputy Minister of Foreign Affairs. He served as Egypt's Foreign Minister from 18 February 1935 until 30 January 1936, and was approved by all members to be in the Regency Council. Finally, Sherif Sabri was the king's uncle, so it appeared clear that the chosen council had submitted to plots and vested interests.

The Regency Council members had the right to rule the country completely. They formed a new Cabinet headed by Nahass Pasha which lasted from 5 May 1936 until 31 July $1937^{54}$. They also issued many orders, such as the promotion of First Lieutenant Mahmud Talat on 3 July $1936^{55}$ Although all of their decisions were not vital for Egypt, prince Mohamed Ali complained during this period from Nahass, who treated him as a zero, which was determined to encroach on the powers and prerogatives of the regency council and ultimately to the throne. As Nahass, secretly opened talks with Lampson on March 1936 and he led the delegation to London for signing the treaty ${ }^{56}$. This an important indicator about the limited role of the regents who were responsible just for unimportant matters but the political life was left for the prime minister. There were attempts by Prince Mohammed Ali to prolong the regency period, but he failed, and a ruling was extracted from the President of the Supreme Legitimacy Court, allowing the minor king to be responsible for his own wealth; an order was issued in this matter in May 1936. After that Farouk was appointed as a director of Khedive Ismail Endowments, away from the Regency Council ${ }^{57}$. The Wafd party also demanded raise the age of majority to Twenty-one; giving the Wafd-appointed Regency Council four years to rule, but the Cabinet refused this request ${ }^{58}$.

This was the most famous case of regency in modern Egypt. It reflected the new constitutional life in which both the government and the parliament were responsible for regency matters, and not the Sublime Porte, as in previous cases. Also in this case the regents had the ability to act like the real rulers in all state affairs, and without any permission from the ruler, but the real power was in the hands of the prime minister.

\section{Regency of King Ahmed Fouad II}

According to the succession law, the time came for Farouk's son to assume the throne, but circumstances had changed. On this occasion, it made little difference whether the crown prince's age was calculated on the basis of the Islamic or Georgian calendar, as Prince Ahmed Fouad II

${ }^{53}$ Aziz Ezzat Pasha was greatly involved with the famous Egyptian sports club Al-Ahly. On 2 April 1908 he became the club's second president. He was the first Egyptian to hold that post, and kept it until 16 April 1914 . He later became Honorary President of the club (1929-1941).

${ }_{55}^{54}$ http://modernegypt.bibalex.org/NewTextViewer.aspx?TextID=DC_20123\&keyword=Regency Council council

55 http://modernegypt.bibalex.org/NewDocumentViewer.aspx?DocumentID=DC_20272\&keywod, regency

${ }^{56}$ Peter L.Hahn, Unites States, Great Britain, and Egypt 1945-1956 Strategy and Diplomacy, ( University of North Carolina press, 1991),p.11

${ }_{57}$ Al Ahram Newspaper, issue 18459, 4 May 1936.

${ }^{58}$ Akher Saca Newspaper, issue 209, 3 July 1938. 
was just six months old. In addition, Farouk ascended the throne after the death of his father, whereas Fouad II was declared king after his father was deposed ${ }^{59}$.

Moreover, Farouk was deposed neither by the Sultan in Istanbul, as was the case with his grandfather Khedive Ismail in 1879, nor by the British as was the case with his uncle Abbas Helmi II when Great Britain declared its protectorate over Egypt, but by the Egyptian army in the 1952 July Revolution. The 1952 July Revolution did not abolish the monarchy immediately, as this step needed to be well prepared for, to accommodate internal public opinion and to avoid external intervention. King Farouk I abdicated in favour of his six-month-old son Ahmad Fouad, who ascended the throne as King Fouad II. However, he only reigned as a nominal king in exile ${ }^{60}$.

There was confusion after the deposition of Farouk concerning the question of Fouad II's regency. The relevant articles of the constitution 51 and 52 refer to the death of the king, and nothing mentioned about the abdication of him. Article 52 said that if the chamber is in dissolution at the time of king's death and its date of convocation is after the period of ten days from the death, the old chamber resumes the functions ${ }^{61}$. Initially, Ali Maher's cabinet, assumed the powers of the king. A week later, on 2 August $1952^{62}$, guidance on the constitution issue is difficult, Aly Maher obviously requires some legal basis and some support other than tanks, theoretically to follow the spirit of the constitution. Convoke the chambers, and swear in a regency council would give him the legal authority he asked, but in practice as the old chamber was Wafdist and there was a Wafd majority in the Senate there was a danger in convoking them.

On the other hand, if the arbitrary rule is to continue, it will be more and more rule by the military officers and by the more energetic obstinate and violent one's force had put Aly Maher in, and will control him if he tries to rule without a parliament, unless he has some extraordinary good understanding with the army; which does not seem to be quite the case. The least evil course would seem to be to stretch the letter of the constitution a bit gets a regency council of men whom the public generally would approve and the Revolution Command Council, and then proceed with electoral reform and administration. Cleaning up, putting off the elections until this has been done.

The Wafd was apparently relying on Article 52 which said that if the chamber is in dissolution at the time of the king's death and its date of convocation is after the period of ten days from the death, the old chamber resumes its function. Nahass view had been that the regency should be composed of Aly Maher as senior regent together with Barakat pasha and Sirii pasha. Prince Mohamed Ali Tewfik sent a telegram for the British embassy, saying that both the Wafd and the soldiers expressed themselves in favour of a regency council without representing a member of the Royal family, he asked to be the representative in the regency council because of his right as the elder of the royal family, but his demand was rejected by the Revolutionary Council. ${ }^{63}$ Both the Wafd and the members of the royal family wanted to be represented in the regency council, but the decision of choosing the regents was in the hands of the officers only. This time the British

\footnotetext{
${ }^{59}$ Life, Vol.33, No.6, 11 August 1952.

${ }^{60}$ Anne Alexander, Nasser, (Haus Publishing Limited, London, 2005), p. 49.

${ }^{61}$ F.O. 141-1453, No.85749, Secret, 28 July 1952.

${ }^{62}$ Assa Okoth, A History of Africa, Vol.2, (East African Educational Publishers Ltd., Kenya, 2006), p. 200.

${ }^{63}$ F.O. 141-1453, No.85749, Secret, 28 July 1952.
} 
avoided giving any nominations for the regency body, they were watching the situation, although they regarded appointing a member from the royal family in the council is a vital matter to avoid all danger of a constitutional vacuum and to provide a focus for political action in Egypt in the future. ${ }^{64}$ In the weeks following the revolution, Great Britain pursued a policy of giving Ali Maher every encouragement to keep the military under control which he sought to bring stability to Egyptian politics. ${ }^{65}$ So they tried to persuade him by the importance of the existence of a member of the royal family in the regency body.

Aly Maher together with Mohamed Nagiub, the acting leader of the revolution council, could even dispense with the regency council and thus get over the difficulty of its oath before parliament, be decreeing that the council of ministers would continue to exercise the functions of the king until the necessary reforms were carried out and a truly representative parliament could be elected. In principle, a constitution cannot be stretched to cover a constitutional situation for which it does not make provision. It is on the other hand subject to interpretation.

The reliable factor in the situation is that Aly Maher and his ministry were legally appointed by the king before his abdication, a regency council was also nominated constitutionally but the decree of 18 April 1922, is as much an obstacle as article 51 of the constitution to the regents assuming their functions ${ }^{66}$.

It seems however that there were strong reasons against the regents appointed by the king acting before taking the oath legal and probably also political. A temporary Regency Council was then created $^{67}$, consisting of Prince Mohamed Abd El Moneim ${ }^{68}$, Mohamed Bahy El Din Barakat ${ }^{69}$ and Rashad Mhanna ${ }^{70}$.

The leader of the chosen council was Prince Mohammed Abd El Moneim, who was one of the members of the royal family. Mohamed Bahy El Din Barakat was a Wafdist, and not a supporter

${ }^{64}$ F.O. 141-1453, No.85749, telegram from F.O to Alexandria, 28 July 1952.

65 Michael T.Thornhill, "Britain, the United States and the Rise of an Egyptian Leader. The Politicis and Diplomacy of Nasser's Consolidation of Power 1952-1954”, The English Historical Review, vol.119, no.483, September 2004.

${ }^{66}$ F.O. 141-1453, No.85749, Secret, letter by Murray Graham, Legal counselior, 28 July 1952.

${ }^{67}$ F.O. 141-1453, No.85749, Immediate, 30 July 1952.

${ }^{68}$ Prince Mohamed Abd el Moneim was the son of Khedive Abbas Helmi II, he was the heir to the throne, but following the Ottoman Empire's entry into World War I, Muhammad Abdul Moneim's father Abbas II was deposed by Britain on 18 December 1914 for supporting the Ottomans in the War. His father was replaced on the throne by his uncle Hussein Kamel, bypassing Muhammad Abdul Moneim who was demoted in the line of succession.

${ }^{69}$ Bahey El Din Barakat Pasha was the minister of Education in 1930; in 1938 he inaugurated Egypt's radio broadcasting service. He was a leading figure of the Wafd Party during Saad Zaghlul's leadership as well as during the reign of King Farouk I, and he was elected as Speaker of the Chamber of Deputies on 12 April 1938.

${ }^{70}$ Rashad Mehanna was a colonel who contributed largely to the movement of the Free Officers in 1952; he was contacted by Gamal Abdel Nasser in 1949. During the 1951 elections at the Officers' Club, Mehanna was the one who advocated Muhammad Naguib's election. After the Revolution took place in July 1952, Mehanna was appointed Minister of Transport in Ali Maher's ministry. He acted as an intermediary between the Free Officers Committee and the Cabinet, since he was a member of both. In 1953, reports began circulating which indicated that Mehanna was the ringleader of an attempted coup. As a result of this, Mehanna was accused of counterrevolutionary conspiracy and was imprisoned on 30 March 1953. However, he was released in 1956 and then put under house arrest. He was rearrested in 1965, only to be released once again in 1967 . He retired completely from politics after that, and died on 3 January 1996. 
of either the king or the revolution. Rashad Mehanna was chosen by Nasser to serve as a representative of the army on the three-member Regency Body, and the prime minister assured that Mehanna was a very good man. ${ }^{71}$

The Revolution Command Council members choose the regents carefully, so as to satisfy both their needs and external public opinion. It is worth mentioning that the choice of members was away from the Cabinet, and was determined by the RCC members only. This chosen council, however, had no actual powers, as power was assumed by the Revolutionary Command Council. Indeed, this was the main reason for the hostility that arose between Mehanna and Nasser, as Mehanna actually took his title seriously while Nasser and the other members of the RCC had no intention of allowing him to exercise any power ${ }^{72}$.

After just ten weeks of the regency a great conflict happened between Mehanna and the members of the RCC, Mehanna was dealing as a ruler of the country he issued many important orders related to political life in Egypt like stopping the issuance of a newspaper, and dissolving the political parties. He appeared in the newspapers as the ruler of the country, and this was unacceptable act for Nasser and his colleagues. The Regency Body was dissolved on 7 September 1952, after the resignation of Mehanna and Barakat. On 14 October 1952 the RCC had his statement about the resignation of Mehanna with these words" The army has nominated one of his officers to the district office staff of war Rashad Mehanna in the regency council and he asked him to stick to the limits of his job as a regent, has nothing to do with governance, but he connects with the ministers asking for many demands, and he was alerted several times but he neglected our orders, he admitted himself to object in public about the agriculture law, so it was necessary to accept his resignation". ${ }^{73}$ This was a strange matter as Mehanna was a regent and the regent as we defined before is a ruler so why they did not want him to act as a ruler?, it seems that they need just puppets without any powers, that it was Mehanna's right to have any decisions relating to political, social, and economic life in Egypt.

Prince Muhammad Abdel Moneim (fig.VIII) was appointed as sole Prince Regent, without any real power. By this time, it must have been clear what the RCC had something in mind for the monarchy. It was not long before it took a decisive action, ending the dynasty that had ruled Egypt for nearly a century and a half.

However, throughout this period, the real power lay in the hands of the Revolutionary Command Council. The monarchy was formally abolished on 18 June 1953. Egypt was declared a republic, and Muhammad Naguib became its first ever President ${ }^{74}$.

\footnotetext{
${ }^{71}$ F.O. 141-1453, No.85749, Immediate, 30 July 1952.

72 Steven A. Cook, The Struggle for Egypt from Nasser to Tahrir Square, (Oxford University press, 2012), p. 55.

${ }^{73}$ Mohamed Naguib, Kont Raesan li Masr,2nd edition, ( Al Maktab Al Masry Al hadeeth, Alexandria, 1984), p.155.

${ }^{74} \mathrm{http}: / /$ nasser.bibalex.org/Decisions/DECcontent.aspx?src=Search\&lang=ar
} 
So, there were two regency cases after the revolution, one for a council and the other for a sole regent, and this case differs from other cases, as another power was controlling the country and not the Regency Council. The regent also did not issue any decision during his rule.

Table I, The Regents in Modern Egypt

\begin{tabular}{|l|l|}
\hline \multicolumn{1}{|c|}{ Regent } & Date \\
\hline Ibrahim Pasha & $1847-1848$ \\
\hline Ismail & $1861-1862$ \\
\hline Regency council (Ismail Seddiq-Ismail Ragheb-Mohamed Sherif Pasha) & 1867 \\
\hline Tewfik & 1870 \\
\hline Regency council (Prince Mohamed Ali- Aziz Ezzat- Sherif Sabri Pasha) & 1936 \\
\hline $\begin{array}{l}\text { Regency council (Prince Mohammed Abd El Moneim- Mohamed Bahy El Din } \\
\text { Barakat- Rashad Mehanna }\end{array}$ & 1952 \\
\hline Prince Mohamed Abd El Moneim (the last regent in Modern Egypt) & $1952-1953$ \\
\hline
\end{tabular}

\section{Conclusion}

Regency was used widely as a ruling tool in modern Egypt, in the case where the regent was the son of the ruler, he could rule alone, but if the regent was not a son, a council was formed to prevent any attempts by a sole regent to take over the throne. The regency in the case of the absence of the ruler was determined for a specific period even for his son, this period was from one month to three months or with writing the sentence "just the absence period". There were advantages of the regency system, as it prepared the future heir well for rule, and was considered a training period for the regent. The foreign interference in the regency process appeared only during the minority of the ruler and they did not interfere neither during the incapability nor the absence of the ruler, as the minority continued for a long time this would in turn affect them, but the absence was for short time. The regents all over Egypt's modern history did not take any dicisson on which in turn affected the political life or was considered as a turning point in the history, they were just stations not more, the only regent who was with full power was Ibrahim pasha son of Mohamed Ali. Finally, the regency system changed completely after the 1952 Revolution, as the regents did not have any rights to take any vital or inessential decisions, as power was in the hands of the Revolutionary Command Council.

\section{References}

Abd El Rahman El Rafcy, Asr Mohammed Ali, $5^{\text {th }}$ edition, (Dar El Marf, Cairo, 1989).

, Asr Ismail, Vol.I, 4th edition, (Dar El Macrf, Cairo, 1987).

Al Ahram Newspaper, issue 18452, 27 April 1936.

Al Ahram Newspaper, issue 18453, 28 April 1936.

Al Ahram Newspaper, issue 18455, 30 April 1936.

Al Ahram Newspaper, issue 18459, 4 May 1936.

Actes Diplomatiques et Firmans Imperiaux Relatifs a L'Egypt, (Cairo, 1880).

Afaf Lutfi Alsayed Marsot, A Short History of Modern Egypt, (Cambridge University Press, 1985).

Egypt in the Reign of Mohammed Ali, (Cambridge University Press, 1984). 
Akher Saca Newspaper, issue 209, 3 July 1938.

Alwaqaec Almasrya, issue 517, 17 July 1873.

Albert De Burton, Ten Months' Tour in the East, (F. Bowyer Kitto Bishops Gate, London, 1870).

Arthur Goldschmidt JR, A Brief History of Egypt, (InfoBase Publishing, New York, 2008).

Assa Okoth, A History of Africa, Vol.2, (East African Educational Publishers Ltd., Kenya, 2006).

Anne Alexander, Nasser, (Haus Publishing Limited, London, 2005).

Beshara Boumani (ed.), Family History in the Middle East, Household, Property, and Gender, (State University, New York, 2003).

Robert Fitzgerald, The Rise of the Global Company. Multinationals and the making of the Modern World,

(Cambridge University Press, 2015).

Enas Fares Yehia, "Prince Mohamed Ali after the July Revolution 1952 and the Journey of Searching for the Lost", Journal of the American Research Center In Egypt(JARCE), Vol.51, 2015, p.197.

Evelyn Baring, Modern Egypt, (Cambridge University Press, 2010).

El Ethad Newspaper, 20 January 2006, by Helmi El Namnm.

F. Robert Hunter, Egypt under the Khedives 1805-1879. From Household Government to Modern Bureaucracy, (AUC Press, Cairo, 1999).

F.O. 371-20107, 20105, J 3560-2-16, Lampson, F.O., Cairo, 27 April, 1936.

F.O. 371-20107, 20106, J4105, Lampson-F.O., Cairo, 11 May 1936.

F.O. 141-1453, No.85749, Secret, 28 July 1952.

F.O. 141-1453, No.85749, Secret, 28 July 1952.

F.O. 141-1453, No.85749, telegram from F.O to Alexandria, 28 July 1952.

F.O. 141-1453, No.85749, Secret, letter by Murray Graham, Legal counselior, 28 July 1952.

F.O. 141-1453, No.85749, Immediate, 30 July 1952.

F.O. 141-1453, No.85749, Immediate, 30 July 1952.

Hassan Yousif, AlQasr wa Doroh fi Alsyasah Almasryia 1922-1952, (A Ahram Center for Political and Strategic Studies, Cairo,1982).

J. S. Buckingham, Esq., M. P. (ed.), The Parliamentary Review, Vol II, Session of 1834, (London, MDCCCXXXIV).

Khaled Fahmy, All the Pasha's Men, Mohamed Ali. His Army and the Making of Modern Egypt, (AUC Press, Cairo, 1997)

Latitia W. Ufford, The Pasha, How Mehmet Ali Defied the West 1839-1841, (McFarland Company Inc. Publishers, Carolina, 2007).

Latifa Mohammed Salim, Farouk wa Seqwat El Malakya fi Masr 1936-1952, (Maktabt Madbouly press, Cairo,1989).

Lesley Lababidi, Cairo's Street Stories, (AUC press, Cairo, 2008).

Life, Vol.33, No.6, 11 August 1952.

Melvin E. Page and Penny M. Sonnenburg (ed.), Colonialism. An International Social, Cultural, and Politica Encyclopedia, (ABC. CLIo, Inc. California, 2003).

Michael Avi. Yonah (ed.), A History of Israel and the Holy Land, (The Continuum International Publishing Group Inc, New York, 2001). 
Michael Herb, All in the Family, Absolutism, Revolution, and Democracy in the Middle Eastern Monarchies, (State University Press, New York, 1999).

Michael T. Thornhill, "In Search of King Farouk the Mohammed Ali Dynasty and the Decline of British Imperialism in Egypt", Challenging Retrenchment, the United States, Great Britain, and the Middle East 1950-1980, Tore T.Petersen(ed.), ( Tapir Academic Press, Trondheim, 2010).

Michael T.Thornhill, "Britain, the United States and the Rise of an Egyptian Leader. The Politicis and Diplomacy of Nasser's Consolidation of Power 1952-1954”, The English Historical Review, vol.119, no.483, September 2004.

Mohamed Naguib, Kont Raesan li Masr,2nd edition, ( Al Maktab Al Masry Al hadeeth, Alexandria, 1984).

Nadia Ramses Farah, Egypt's Political Economy. Power Relations in Development, (American University in Cairo press, 2009).N.C. Chattervi, Muddle of the Middle East, (Abhinav Publications, New Delhi, 1973)

Percy F.Martin, Egypt- Old and New, (Rutledge Press, New York, 1923).Peter L.Hahn, Unites States, Great Britain, and Egypt 1945-1956 Strategy and Diplomacy, ( University of North Carolina press, 1991)Prince Mohammed Ali Tewfik, Bacd Wathaq Tarekhya mn Ahdy Sakeny Aljenan Ismail Pasha wa Tewfik Pasha, (Cairo, 1948).

Pierre Crabites, Ibrahim of Egypt, (Rutledge, New York, 2013)

Stanford J. Shaw and Ezel Kural Shaw, History of the Ottoman Empire and Modern Turkey. Reform, Revolution, and Republic, Vol. II, (Cambridge University Press, 1977).

Steven A. Cook, The Struggle for Egypt from Nasser to Tahrir Square, (Oxford University press, 2012).

Sylvanus Urban, Gent, The Gentleman's Magazine, Vol. 31, (John Bower Nichols and Son, London, 1849).

The Illustrated London Almanac, (Office,198, Strand, 1868).

Sydney Morning Herald Newspaper, 28 April 1936.

Published documents in the site of Alexandria library" Memory of Modern Egypt":

http://modernegypt.bibalex.org/NewTextViewer.aspx?TextID=DC_20123\&keyword=Regency Council, accessed 12 March 2017

http://modernegypt.bibalex.org/NewDocumentViewer.aspx?DocumentID=DC_20272\&keywod, regency council, accessed 12 March 2017

http://nasser.bibalex.org/Decisions/DECcontent.aspx?src=Search\&lang=ar, accessed 12 March 2017 


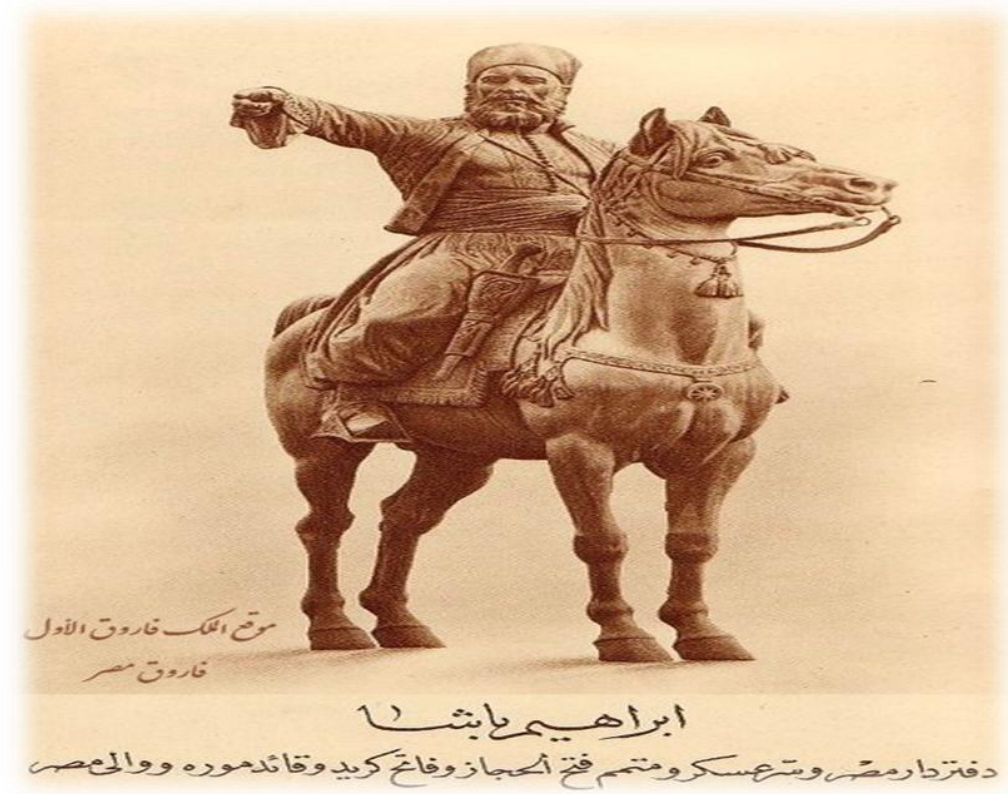

Fig.I, Ibrahim Pasha

After, http://faroukmisr.net/royalfamely.htm

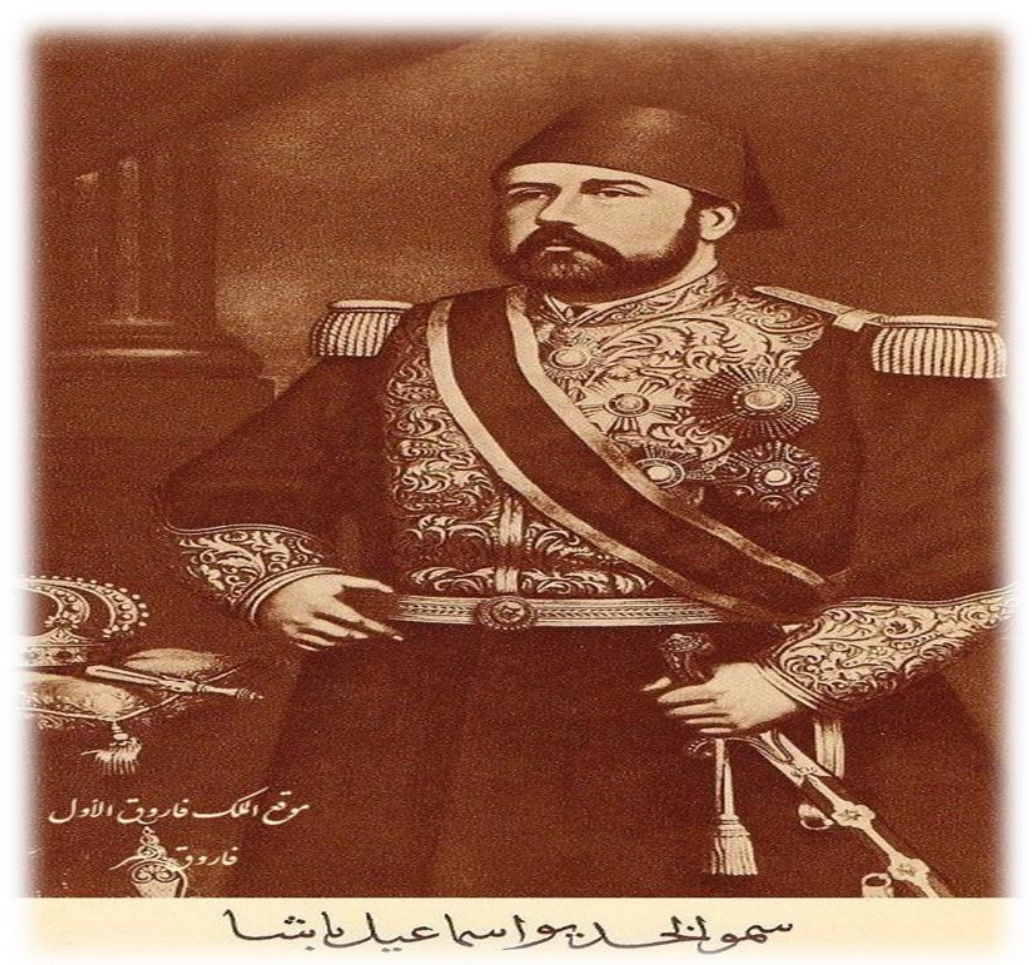

Fig.II, Khedive Ismail

After, http://faroukmisr.net/royalfamely.htm 


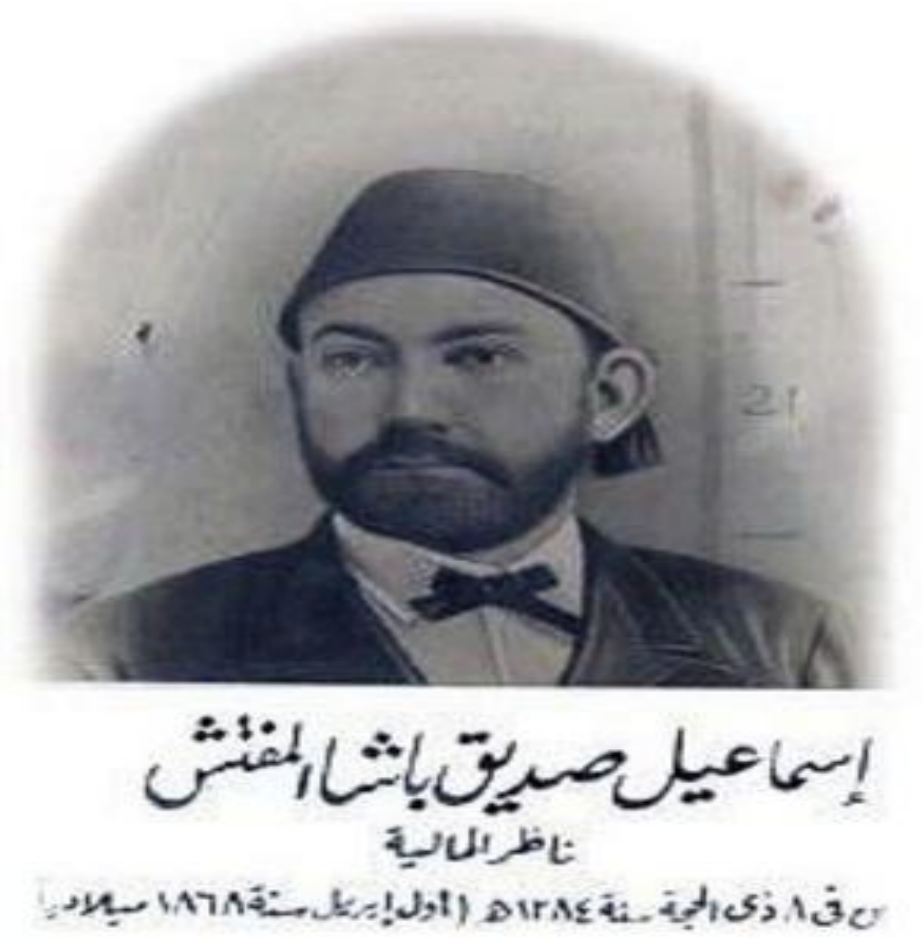

fig.III, Ismail Seddiq after, http://www.faroukmisr.net/report57.htm

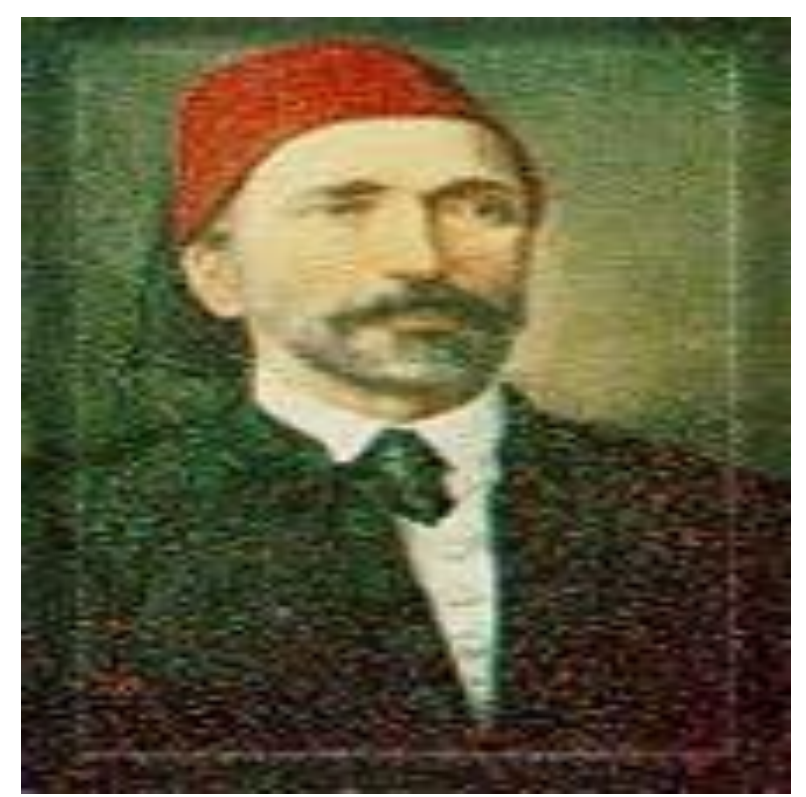

Fig. IV, Ismail Pasha Ragheb

After,

http://modernegypt.bibalex.org/NewViewer.aspx?albumName=IM_585\&currentImage=IM_1394 $2 \&$ ImageIndex $=0 \&$ keyword 


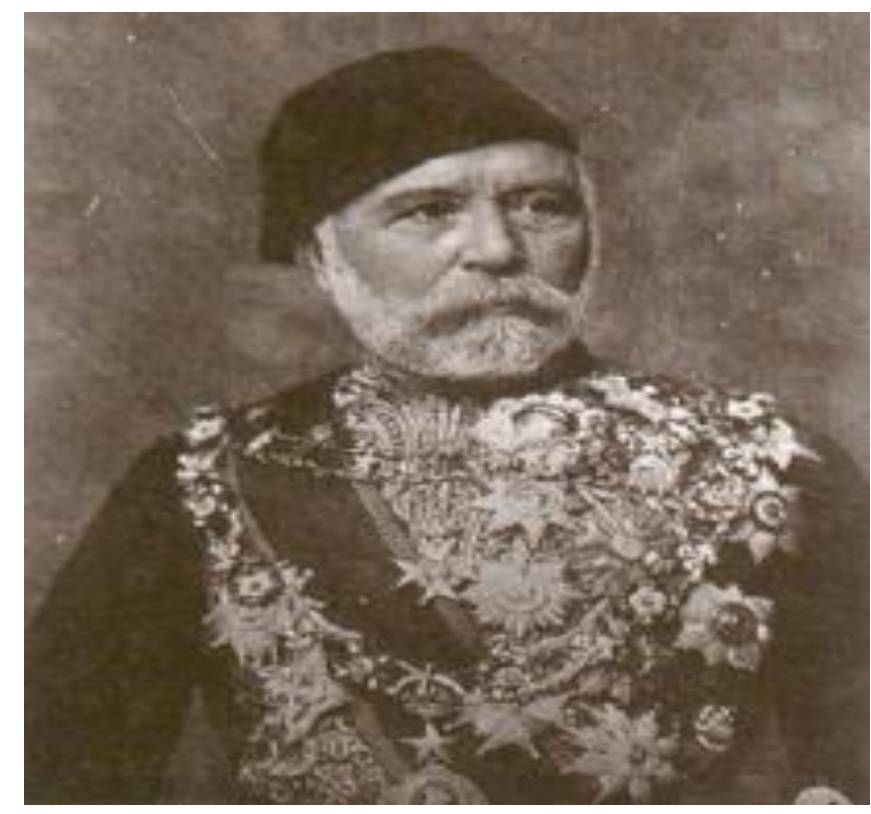

Fig.V, Sherif Pasha

After, http://www.marefa.org/index.php

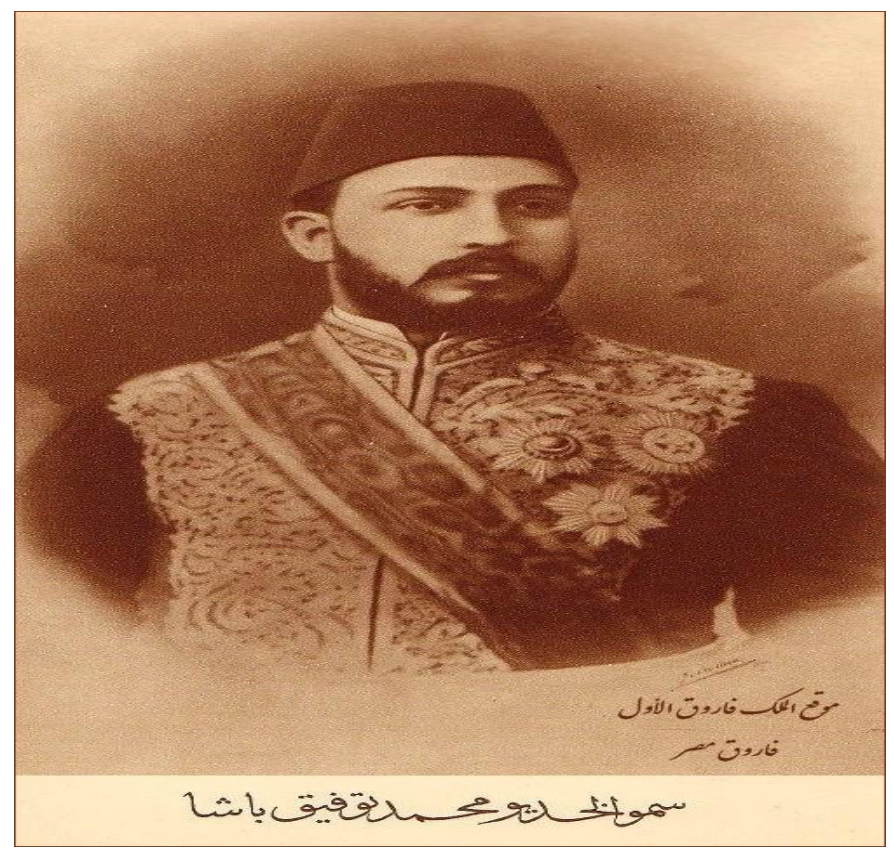

Fig.VI, Tewfik Pasha

After, http://faroukmisr.net/royalfamely.htm 


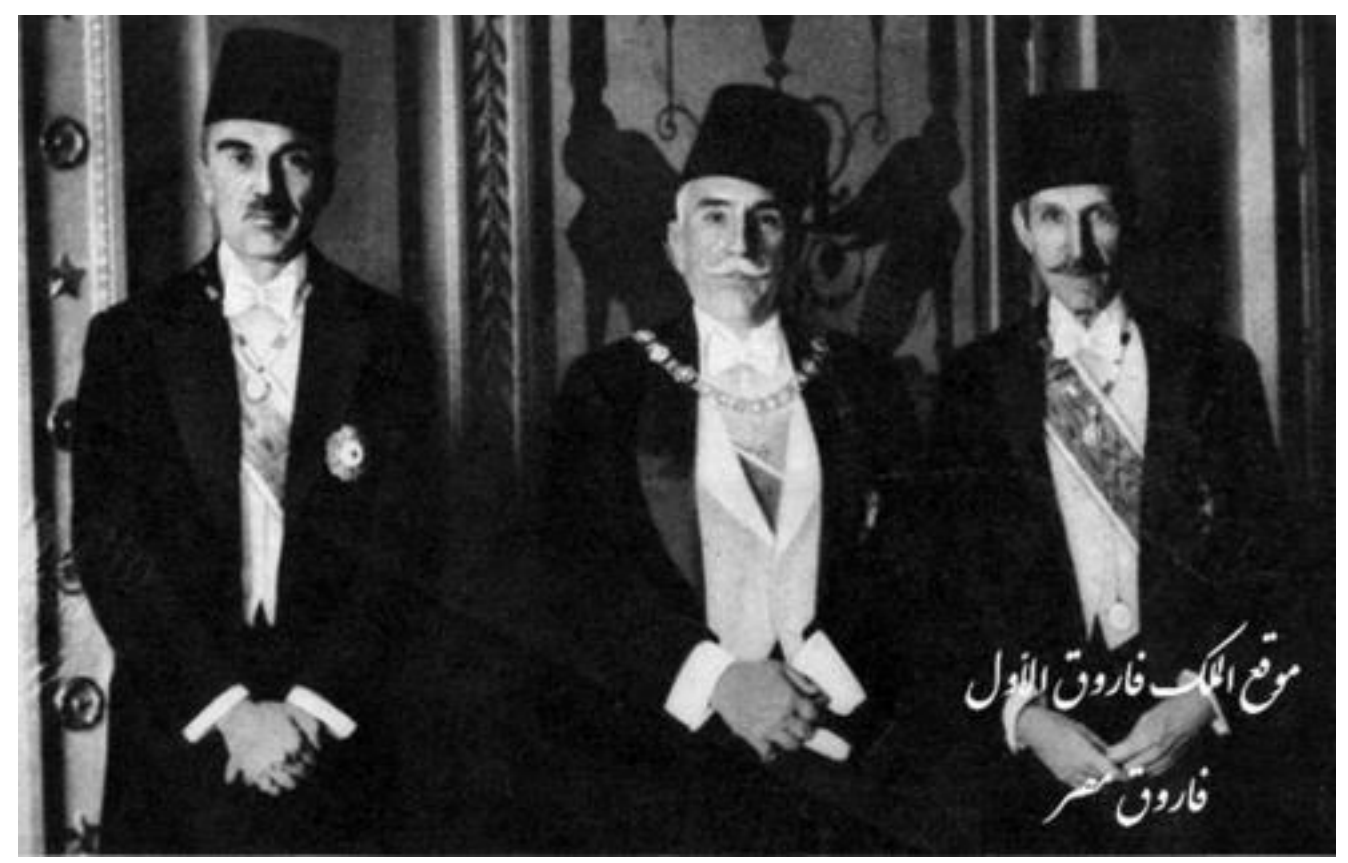

Fig.VII, The Regency Council, Prince Mohammed Ali as head of the council (center), Aziz Ezzat (right), and Sherif Sabri Pasha(left)

(after http://www.faroukmisr.net/p_mali.htm).

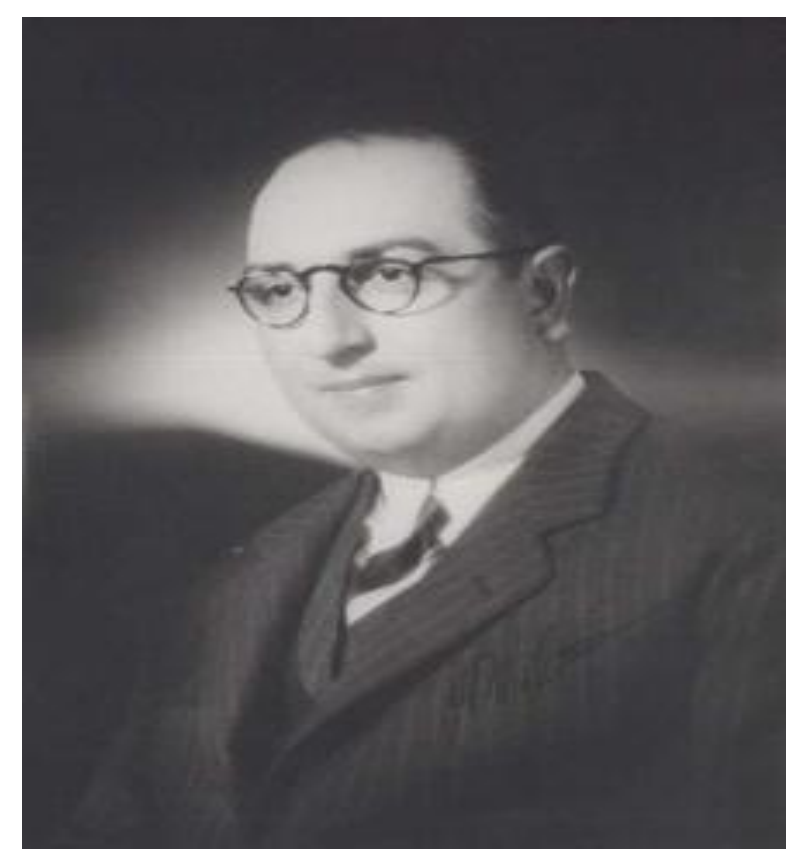

Fig.VIII, Prince Mohamed Abd El Moneim

After,https://ar.wikipedia.org/wiki/:Prince_Muhammad_Abdel_Moneim.jpg 